\title{
In memory of Professor Takayuki Ono
}

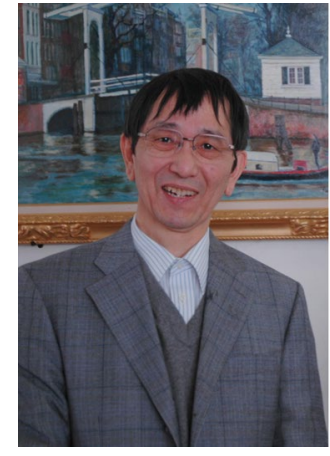

精ー杯のチャレンジを! 成功を祈ります

小野高幸

he did not live long enough to witness the launch of the ERG (Arase) satellite on 20 December 2016 to which he had dedicated to so much of his life. His warm character appeared to everyone, and he had always encouraged young colleagues to realize the project.

Professor Ono was born on 5 August 1950. He graduated and received a Ph.D. from Tohoku University. He moved to National Institute of Polar Research in 1980. He came back to Tohoku University to take up the position of an associate professor and was promoted to a full professor in 2000. He is survived by his wife Naomi, four children, and five grandchildren.

Professor Takayuki Ono of Graduate School of Science, Tohoku University, passed away on 21 December 2013. He was 63 years old. He was the Principal Investigator of the Geospace Exploration Mission: Exploration in energization and Radiation in Geospace (ERG) and played the leader of the ERG project. It is very unfortunate that

Y. Miyoshi, T. Takashima, K. Asamura, and I. Shinohara

\section{Publisher's Note}

Springer Nature remains neutral with regard to jurisdictional claims in published maps and institutional affiliations.

Published online: 31 October 2018 